\title{
12-17 METŲ KREPŠININKŲ ŠIRDIES ECHOKARDIOGRAFINIŲ IR FUNKCINIŲ RODMENŲ YPATUMAI
}

\author{
Aldona Bartkevičiene் $\dot{e}^{1,4}$, Alfonsas Vainoras ${ }^{2}$, Dalia Bakšienè2, \\ Nijolė Raškauskien $\dot{e}^{1}$, Sigita Kibildiené $\dot{e}^{3}$ \\ KMU Psichofiziologijos ir reabilitacijos institutas ${ }^{l}$, Palanga, \\ Kauno medicinos universitetas ${ }^{2}$, Kaunas, Klaipedos sporto medicinos centras ${ }^{3}$, \\ Klaipédos vaiku ligonine $\dot{4}^{4}$,Klaipéda, Lietuva
}

\begin{abstract}
Aldona Bartkevičienė. Medicinos mokslų magistrè. Kauno medicinos universiteto Psichofiziologijos ir reabilitacijos instituto jaunesnioji mokslo darbuotoja. Tyrimo kryptis — sportuojančių vaikų ir paauglių kairiojo skilvelio morfometrinių rodiklių funkcijos bei širdies ir kraujagyslių sistemos funkcinių rodmenų ypatumai.
\end{abstract}

\section{SANTRAUKA}

Iki šiol nepakanka tyrimu, nagrinejjančiu vaiku ir paaugliu, kultivuojančiu krepšini, širdies morfometrijos bei širdies ir kraujagysliu sistemos (ŠKS) adaptacija prie ilgalaikio fizinio krūvio. Tyrimo tikslas - ištirti ir palyginti 12 - 17 metu krepšininku ir nesportuojančiuju kairiojo skilvelio echokardiografinius rodmenis, išanalizuoti funkciniu rodmenu kitimo greičio kaitos ypatumus veloergometrinio méginio metu.

Ištirti 62 berniukai, kultivuojantys krepšini, ir 168 sveiki nesportuojantys to paties amžiaus, lyties vaikai ir paaugliai.

Tiriant vienmačiu M metodu iprastinejje parasternalinèje pozicijoje atlikti visu tiriamuju standartiniai matavimai diastolès metu: 1) tarpskilvelinès pertvaros storis (TSP, mm); 2) kairiojo skilvelio (KS) užpakalinés sienelés storis (KSUS, mm); 3) KS galinis diastolinis dydis (KSGDd, mm). Pagal formules apskaičiuoti: KS miokardo mase (KSMM), KS miokardo masés indeksas (KSMMI), KS santykinis sieneliu storis (SSS), KS frakcinis sutrumpejjimas (FS) ir santykiniai (koreguoti pagal kūno paviršiaus plota) echokardiografiniai rodmenys - TSP / KPP ${ }^{1 / 2} K S U S / K P P^{1 / 2} K S G D d / K P P^{1 / 2}$ $M M / K P P^{3 / 2}$. Doplerinès echokardiografijos metu užrašius transmitralinès kraujotakos kreive ir išmatavus E ir A greiti, apskaičiuotas E / A santykis. Visi tiriamieji atliko veloergometrinį méginį. Tirti šie rodmenys ir ju kitimo greičiai: širdies susitraukimo dažnis (ŠSD), R-R intervalas (RR), intervalas $J-T(J T)$, sistolinis arterinis kraujospūdis (S), diastolinis arterinis kraujospūdis (D), pulsine amplitude $(S-D)$ ir išvestinis dydis - santykine repoliarizacija JT / RR.

Tyrimas parodè, kad visi absoliutūs ir santykiniai krepšininku echokardiografiniai rodmenys (TSP, KSGDD, KSUS, $M M, M M I, S S S$, TSP / KPP $\left.P^{1 / 2}, K S U S / K P P^{1 / 2}, K S G D D / K P P^{1 / 2}, M M / K P P^{3 / 2}\right)$ buvo didesni už nesportuojančiuju ( $p<0,001)$. Krepšininku kairiojo skilvelio FS ir E / A santykis reikšmingai nesiskyré, palyginti su nesportuojančiu analogiškais duomenimis. Nustatyta, kad krepšininku ŠSD kitimo greitis visq fizinio krūvio méginio laikotarpi, išskyrus šešta minutę, o JT intervalo kitimo greitis - šešta minutę buvo patikimai mažesni už nesportuojančiu tiriamuju $(p<0,05)$. Fizinio krūvio pradžioje buvo nustatytas neigiamas koreliacinis ryšys tarp sportuojančiu tiriamuju KSMM ir ŠSD kitimo greičio, kuris stiprèjo didinant fizini krūvi.. Apibendrinant šio tyrimo rezultatus galima teigti, kad ilgalaikis fizinis krūvis veikia kairiojo skilvelio persimodeliavima ir funkciniu rodmenu ypatumus jau vaikysteje. Tarp krepšininku kairiojo skilvelio MM ir ŠSD kitimo greičio yra glaudus ryšys.

Raktažodžiai: širdies ir kraujagysliu sistema, echokardiografija, funkciniu rodmenu kitimo greitis, kairiojo skilvelio miokardo masé.

\section{IVADAS}

$\mathrm{M}$ okslinejje literatūroje netrūksta duomenų apie suaugusiu sportininkų širdies ir kraujagyslių sistemos (ك̌KS) adaptaciją prie fizinio krūvio (Fagard, 1997; Pelliccia et al., 1999; Pluim et al., 2000). Tačiau ilgalaikio fizinio krūvio poveikis širdies struktūrai bei ŠKS funkcijai gerokai mažiau ištirtas, nors sportuojančių vaiku ir paauglių daugèja (Cohen et al., 1987; Rowland, 1996; Somauroo et al., 2001; Ayabakan, 2006).

Ilgalaikis ir nuolatinis fizinis krūvis veikia daugeli organizmo sistemų. Širdies ir kraujagysliu sistema yra viena iš svarbiausių visoje adaptacijos prie ilgalaikio fizinio krūvio mechanizmu grandinejje. Dèl ilgalaikio fizinio krūvio persitvarko širdies raumens geometrija, kitaip vadinama fiziologine kairiojo skilvelio hipertrofija arba „sportininko širdimi““ (Fagard, 1997; Pluim et al., 2000). Sportininkų širdies persimodeliavimas priklauso nuo fizinio krūvio apimties, intensyvumo, treniravimosi trukmès (stažo) ir sporto šakos pobūdžio (Fagard, 1997). Ši fiziologinè hipertrofijos forma — sportininko širdis — priimama kaip 
palankus adaptacijos prie nuolatinio fizinio krūvio rezultatas. Tačiau labai svarbu atskirti fiziologinę sportininkų širdies hipertrofiją nuo patologinès būsenos, t. y. hipertrofinès ir dilatacinès kardiomiopatijos, galinčių sukelti staigią mirti. Šrirdies ir kraujagyslių sistemos funkcinès galimybès dažnai tampa veiksniu, ribojančiu organizmo adaptaciją prie fizinio krūvio (Winsley et al., 2003). Intensyvaus ir nuolatinio fizinio krūvio metu gali būti viršijamos vaikų ir paauglių organizmo fiziologiniu pokyčių ribos. Neatsižvelgiant į tai, gali kilti pavojus sveikatai ir net gyvybei.

Fizinio krūvio metu intensyvejja ne tik ŠKS ar raumenų veikla, bet vyksta pokyčiai visame organizme (Biggiero, 2001). Todèl norint įvertinti sportininkų ịvairių sistemų funkcijas, ryšius tarp jų ir sistemini organizmo atsaką i fizini krūvị nagrinėjami ne tik atskirų rodmenų pokyčiai. Lietuvoje pradèta domètis suaugusių sportininkų organizmo sistemine adaptacija prie fizinio krūvio (Vainoras ir kt., 1999; Žumbakytė, 2007). Tačiau tiek Lietuvos, tiek pasaulinejje mokslinèje literatūroje nepakanka tyrimų, nagrinėjančių sportuojančių vaikų ir paauglių ŠKS funkcinę būklę ir sisteminę organizmo reakciją i fizini krūvị. Sportuojančių vaikų ir paauglių širdies ir kraujagyslių sistemą veikia ne tik intensyvus nuolatinis fizinis krūvis, bet ir organizmo augimas, brendimas (Rowland, 1996). Vaikui augant, jo širdies ir kraujagyslių sistema nuolatos kinta: didejja širdies svoris, tūris, kinta jos struktūra, vystosi organizmo fiziologinès funkcijos ir nusistovi tam tikri ryšiai tarp atskirų organizmo funkcinių sistemų. Todèl nagrinėjant sportuojančių vaikų ir paauglių širdies ir kraujagyslių sistemos adaptaciją prie fizinių krūvių reikia atsižvelgti $\mathfrak{i}$ vaiko amžiu, ịvertinti brendimo veiksni ir antropometrinių duomenų poveikị.

Suaugusių sportininkų širdies ir kraujagysliu sistemos adaptacija prie ilgalaikio fizinio krūvio yra pakankamai ištirta, tačiau stokojama mokslinių tyrimų, kuriais būtų išanalizuota sportuojančių vaikų ir paauglių širdies ir kraujagyslių funkcinẻ būklè bei sisteminè organizmo reakcija ị fizini krūvị, funkcinès būklès skirtumai. Norint laiku diagnozuoti sportuojančiu vaikų ŠKS ligas, nustatyti organizmo patologinę būseną, persitreniravimą, individualizuoti fizini krūvi, kasdienejje medicinos praktikoje svarbu įvertinti sportuojančių vaikų ir paauglių ŠKS adaptaciją prie ilgalaikio fizinio krūvio.

Tyrimo tikslas - ivertinti krepšinio sporto šakos pratybų poveiki $12-17$ metų berniukų kairiojo skilvelio morfometrijos, funkcijos ir ŠKS funkcinių rodmenų kaitai.

\section{TYRIMO METODIKA IR ORGANIZAVIMAS}

Tyrimas atliktas gavus Kauno regioninio biomedicininiu tyrimu etikos komiteto leidimą (protokolo Nr.151/2007). Tiriamieji ir jų tėvai buvo informuoti apie tyrimą, jo tikslus, pasirašè informuoto asmens sutikimo formą.

Tirti $12-17$ metu berniukai $(\mathrm{N}=62)$, kultivuojantys krepšinio sporto šaką.

Kontrolinę grupę sudare to paties amžiaus ir lyties 168 sveiki nesportuojantys vaikai ir paaugliai. Tiriamujų grupių amžiaus, antropometrinių duomenų, krepšininkų treniravimosi stažo ir treniravimosi apimties vidurkiai bei standartiniai nuokrypiai pateikti 1 lentelèje.

Tiriamieji buvo pasverti naudojant medicinines svarstykles, pamatuotas jų ūgis. Korotkovo metodu kairès rankos žasto srityje buvo išmatuotas arterinis kraujospūdis.

Echokardiografinis tyrimas atliktas Philips aparatu (Philips Medical Systems, 22100), naudojant 3,5 MHz davikli. Visi matavimai atlikti atsižvelgiant ¡ Amerikos kardiologų draugijos ir Amerikos širdies asociacijos parengtas metodines rekomendacijas (Lang, 2005). Tiriant vienmačiu M metodu parasternalinejje ilgosios ašies pozicijoje buvo atliekami visų tiriamujų standartiniai matavimai: tarpskilvelinès pertvaros storis diastolès metu (TSP), kairiojo skilvelio galinis diastolinis dydis (KSGDd), KS galinis sistolinis dydis (KSGDs), kairiojo skilvelio užpakalinès sienelès storis diastolès metu (KSUS). Kairiojo skilvelio masė (KSMM) apskaičiuota taikant Penn konvencijoje priimtą R. B. Devereux (Lang, 2005) formulès korekciją:

$\mathrm{KS}$ masè $(\mathrm{g})=1,04 \times$

$\left[(\mathrm{TSP}+\mathrm{KSGDd}+\mathrm{KSUS})^{3}-\mathrm{KSGDd}^{3}\right]-13,6$

KS masès indeksas (MMI) apskaičiuotas KS masę padalijus iš kūno paviršiaus ploto (KPP, $\mathrm{m}^{2}$ ). Santykinis kairiojo skilvelio sienelių storis (SSS) apskaičiuotas susumavus tarpskilvelinès pertvaros ir kairiojo skilvelio užpakalinès sienos storius ir gautą sumą padalijus iš kairiojo skilvelio skersmens diastolès metu. Kūno paviršiaus plotas (KPP) apskaičiuotas taikant standartinę formulę (Du Bois, 1916):

$$
\begin{aligned}
& \mathrm{KPP}\left(\mathrm{m}^{2}\right)=(\overline{\mathrm{u} g i s}(\mathrm{~cm}))^{0,725} \times \\
& (\mathrm{kūno} \text { masè }(\mathrm{kg}))^{0,425} \times 0,007184
\end{aligned}
$$

Noredami ivertinti antropometriniu duomenu ir širdies echokardiografinių rodmenų sąsajas, apskaičiavome ne tik absoliučiuosius, bet ir santykinius (koreguotus pagal kūno paviršiaus plo- 
tą) echokardiografinius rodmenis. Skaičiavimo metodika: tarpskilvelinès pertvaros (TSP) storị, KS užpakalinès sienos (KSUS) storị ir KS galini diastolini dydi (KSGDd), išreikštus milimetrais, padalijome iš kūno paviršiaus ploto, pakelto $1 / 2$ laipsniu, o KS miokardo masę (MM), išreikštą gramais, padalijome iš kūno paviršiaus ploto, pakelto 3/4 laipsniu (Pavlik et al., 2001).

Apskaičiavome šiuos kairiojo skilvelio funkcijos rodmenis:

1) kairiojo skilvelio sistolinei funkcijai vertinti apskaičiavome kairiojo skilvelio frakcini sutrumpejimą:

$$
\mathrm{FS}(\%)=((\mathrm{KSGDd}-\mathrm{KSGDs}) / \mathrm{KSGDd}) \times 100
$$

2) kairiojo skilvelio diastolinei funkcijai vertinti pulsiniu dopleriu diastolès metu išmatavome maksimaluji pradinio kairiojo skilvelio prisipildymo greitį $\mathrm{E}$ ir maksimaluji transmitralinès kraujotakos greiti prieširdžiu kontrakcijos metu A. Diastolinę funkciją îvertinome apskaičiavę E / A santyki.

Tiriamieji atliko veloergometrini mégini $\mathrm{Ar}$ chimed 4220 (Ergocard) aparatu. Buvo taikytas nenutrūkstamas, pakopomis kas dvi minutes didinamas fizinis krūvis iki submaksimalaus ŠSD (85\% maksimalaus ŠSD) arba krūvį ribojančių simptomų. Maksimalus ŠSD apskaičiuotas pagal formulę:

$$
\text { maksimalus ŠSD = } 220-\text { amžius (m.) }
$$

Veloergometrinio tyrimo metu sinchroniškai kas dvi minutes per kiekvienos krūvio pakopos paskutines 10 sekundžiu buvo užrašyta EKG bei Korotkovo metodu išmatuotas arterinis kraujospūdis.

Veloergometrinis tyrimas atliktas pagal McMaster protokolą (Washington et al., 1994): visi tiriamieji, kurių ūgis mažesnis nei $160 \mathrm{~cm}$, krūvi pradėdavo nuo $25 \mathrm{~W}$ galingumo, kas dvi minutes didindami galingumą po $25 \mathrm{~W}$; tiriamieji, kurių ūgis didesnis nei $160 \mathrm{~cm}$, krūvi pradėdavo nuo $25 \mathrm{~W}$ galingumo, kas dvi minutes didindami galinguma po $50 \mathrm{~W}$. Visi tiriamieji mynè veloergometrą 60 apsukų per minutę dažniu.

Analizuodami funkcinius rodmenis, rèmèmès integralios organizmo reakcijos ị fizinį krūvị modeliu (Vainoras ir kt., 1999). Veloergometrinio tyrimo metu, registruojant funkcinius rodmenis, buvo vertinama triju sistemu - vykdančiosios (veikiančio raumenyno), reguliacinès (apimančios centrinès nervų sistemos, autonomini bei humoralinị valdymą) ir aprūpinančiosios (ŠKS) — veikla ir sąsajos tarp šių sistemų. Pradejjus tyrimą ir per kiekvieną krūvio pakopą buvo registruojami šie funkciniai rodmenys: ŠSD (vertinta visose sinchroniškai registruotose EKG derivacijose, apskaičiuojant kiekvienos kardiociklų serijos vidurki), R-R intervalas (apskaičiuotas pagal formulę $\mathrm{RR}=60 / \mathrm{S} S D$ ), intervalas J-T (JT), sistolinis arterinis kraujospūdis (S), diastolinis arterinis kraujospūdis (D), pulsinè amplitude (S-D) ir išvestinis dydis - santykinè repoliarizacija JT / RR.

J-T intervalo matavimai atlikti II standartinėje derivacijoje, apskaičiuojant rankiniu būdu. Funkciniai rodmenys S ir ŠSD yra labiau susiję su reguliacine sistema, S-D - su periferijos raumenu funkcija ir apibūdina vykdančiosios sistemos atsaką, JT nusako aprūpinančiają sistemą, JT / RR parodo sąsajas tarp reguliacinès ir aprūpinančiosios sistemos. Norint ivvertinti fiziologiniu rodmenu (ŠSD, JT, JT / RR, S, D, S-D) kitimo kiekybinę vertę krūvio metu, apskaičiuotas šių rodmenu kitimo greitis kas antrą krūvio minutę, t. y. kiek fiziologiniai rodmenys didejjo vienam krūvio vatui kas antrą fizinio krūvio minutę.

Greitis apskaičiuotas pagal formulę:

$$
f_{i}=\left(f\left(N_{i+1}\right)-f\left(N_{i}\right)\right) /\left(N_{i+1}-N_{i}\right),
$$

čia $\mathrm{f}_{\mathrm{i}}$ - fiziologinio rodiklio kitimo greitis krūvio metu; $\mathrm{i}=2,4,6,8,10$ krūvio minutę, kai jis didinamas kas 2 minutes; $\mathrm{N}=25,50,75,100,125,150,175 \mathrm{~W}$ galingumas taikytas tiriamiesiems, kurių ūgis mažesnis nei $160 \mathrm{~cm}, \mathrm{~N}=25,75,125$, $175,225,275 \mathrm{~W}$ - kurių ūgis didesnis nei $160 \mathrm{~cm}$.

Statistinė analizė. Aprašomajai rodmenų analizei atlikti naudoti standartiniai statistikos rodikliai: parametru aritmetinis vidurkis, 95\% pasikliautinasis intervalas (PI), standartinis nuokrypis (SN). Tikrinant statistines hipotezes, atitinkančias normaliojo skirstinio kriterijus, buvo taikomi parametriniai (porinis t testas, Pirsono tiesinès koreliacijos koeficientas) ir neparametriniai testai (MannWhitney kriterijus, Spirmeno ranginè koreliacija). Tikrinant statistines hipotezes pasirinktas $\mathrm{p}<0,05$ reikšmingumo lygmuo. Skaičiavimai atlikti naudojant MS Office EXCEL ir SPSS 15.0 for Windows programu paketus.

\section{REZULTATAI}

Tiriamų grupių charakteristika pateikta 1 lentelèje. Krepšininkų amžiaus, svorio ir kūno paviršiaus ploto vidurkiai nuo kontrolinès grupès tiriamujų reikšmingai nesiskyrè. Krepšininkų ūgis buvo didesnis už kontrolinès grupès tiriamuju $(\mathrm{p}<0,05)$.

2 lenteleje pateikiami tiriamų grupių pagrindiniai echokardiografiniai rodmenys. 


\begin{tabular}{|l|c|c|}
\hline \multicolumn{1}{|c|}{ Rodiklis } & Krepšininkai $(\mathbf{n}=\mathbf{6 2})$ & Kontrolinè grupe் $(\mathbf{n}=\mathbf{1 6 8})$ \\
\hline Amžius, $\mathrm{m}$. & $14,9 \pm 1,4$ & $14,8 \pm 1,6$ \\
\hline Treniravimosi stažas, $\mathrm{m}$. & $4,3 \pm 1,9$ & - \\
\hline Treniravimosi apimtis, $\mathrm{h} / \mathrm{sav.}$ & $8,1 \pm 2,3$ & - \\
\hline Ügis, $\mathrm{cm}$ & $178,7 \pm 11,4 *$ & $173,7 \pm 14,0$ \\
\hline Svoris, $\mathrm{kg}$ & $66,7 \pm 14,5$ & $63,4 \pm 13,1$ \\
\hline KPP, $\mathrm{m}^{2}$ & $1,81 \pm 0,24$ & $1,73 \pm 0,19$ \\
\hline
\end{tabular}

1 lentelè. Tiriamųjų charakteristika

Pastaba. Duomenys pateikti: vidurkis \pm standartinis nuokrypis ( $\mathrm{SN})$.

KPP — kūno paviršiaus plotas. $*$ - $\mathrm{p}<0,05$, lyginant su kontrolinès grupès rodikliais.

\begin{tabular}{|c|c|c|c|c|c|}
\hline \multirow[b]{2}{*}{ Rodiklis } & \multicolumn{2}{|c|}{ Krepšininkai $(n=62)$} & \multicolumn{2}{|c|}{ Kontrolinė grupė $(n=168)$} & \multirow[b]{2}{*}{$\mathbf{p}$} \\
\hline & Vidurkis (SN) & $95 \%$ PI & Vidurkis (SN) & $95 \%$ PI & \\
\hline KSGDd, mm & $50,24(4,67)$ & $49,05-51,42$ & $47,59(2,89)$ & $47,15-48,03$ & $<0,001$ \\
\hline TSP, mm & $9,60(1,61)$ & $9,19-10,00$ & $8,41(1,11)$ & $8,25-8,58$ & $<0,001$ \\
\hline KSUS, mm & $9,03(1,55)$ & $8,64-9,43$ & $8,06(1,06)$ & $7,90-8,23$ & $<0,001$ \\
\hline SSS & $0,37(0,047)$ & $0,36-0,38$ & $0,35(0,037)$ & $0,34-0,35$ & $<0,001$ \\
\hline MM, g & $201,02(66,95)$ & $184,02-218,02$ & $149,98(35,92)$ & $144,51-155,45$ & $<0,001$ \\
\hline MMI, g / m² & $108,65(26,07)$ & $102,02-115,30$ & $85,59(14,8)$ & $83,33-87,85$ & $<0,001$ \\
\hline $\mathrm{FS}, \%$ & $38,54(4,06)$ & $37,50-39,58$ & $37,6(2,39)$ & $37,82-38,41$ & $>0,05$ \\
\hline $\mathrm{E} / \mathrm{A}$ & $1,88(0,38)$ & $1,79-1,98$ & $1,89(0,28)$ & $1,84-1,93$ & $>0,05$ \\
\hline $\mathrm{TSP} / \mathrm{KPP}^{1 / 2}$ & $7,31(0,84)$ & $7,18-7,44$ & $6,39(0,70)$ & $6,28-6,49$ & $<0,001$ \\
\hline KSUS / KPP ${ }^{1 / 2}$ & $6,96(0,87)$ & $6,96(0,87)$ & $6,13(0,67)$ & $6,02-6,23$ & $<0,001$ \\
\hline $\mathrm{KSGDd} / \mathrm{KPP}^{1 / 2}$ & $37,99(2,35)$ & $37,64-38,36$ & $36,22(1,80)$ & $36,22(1,80)$ & $<0,001$ \\
\hline $\mathrm{MM} / \mathrm{KPP}^{3 / 2}$ & $86,37(17,8)$ & $83,64-89,09$ & $65,19(10,75)$ & $63,55-66,82$ & $<0,001$ \\
\hline
\end{tabular}

2 lentelè. Krepšininkų ir kontrolinès grupès tiriamųjų echokardiografinių rodmenų palyginimas

Pastaba.

KSGDd - kairiojo skilvelio galinis diastolinis dydis;

TSP — tarpskilvelinès pertvaros storis diastolès metu;

KSUS - kairiojo skilvelio užpakalinès sienelès storis diastolès metu;

SSS - santykinis kairiojo skilvelio sienelių storis;

MM — kairiojo skilvelio miokardo masé;

MMI — kairiojo skilvelio miokardo masès indeksas;

FS - kairiojo skilvelio frakcinis sutrumpéjimas;

A — didžiausias kraujotakos per mitralinị vožtuvą greitis dèl prieširdžio susitraukimo diastolès pabaigoje;

E - didžiausias kraujotakos per mitralinį vožtuvą greitis diastolès pradžioje;

KPP — kūno paviršiaus plotas;

KS — kairysis skilvelis;

$\mathrm{SN}$ - standartinis nuokrypis;

PI - pasikliautinasis intervalas.

Tyrimas parodè, kad krepšininkų tarpskilvelinès pertvaros, KS užpakalinès sienelès, KS santykinis sienelių storis ir KS galinis diastolinis dydis statistiškai patikimai viršijo nesportuojančių tiriamuju atitinkamus echokardiografinius rodmenis $(\mathrm{p}<0,001)$. Krepšininku KS miokardo mase ir KS miokardo masès indeksas patikimai didesni už nesportuojančiujų $(p<0,001)$. Palyginus tiriamuju santykinius (koreguotus pagal kūno paviršiaus plota) echokardiografinius rodmenis nustatyta, kad ir po korekcijos pagal kūno paviršiaus plotą krepšininkų KS masè, tarpskilvelinès pertvaros storis, KS užpakalinès sienelès storis ir galinis skersmuo diastolès metu išlieka didesni už nesportuojančiujų ( $p<0,001)$. Krepšininkų kairiojo skilvelio frakcinis sutrumpejjimas (FS) patikimai nesiskyrè nuo sveikų nesportuojančių tiriamujų. Nustatytas reikšmingai didesnis maksimalusis KS pradinio prisipildymo greitis $E(p<0,001)$ ir maksimalusis transmitralinès kraujotakos prieširdžiu greitis $\mathrm{A}$ kontrakcijos metu $(\mathrm{p}<0,01)$, tačiau E / A santykis tarp grupių reikšmingai nesiskyrè. Tai rodo normalią krepšininkų diastolinę funkciją.

Veloergometrinio tyrimo metu nustatyta, kad krepšininkų ŠSD kitimo greitis mažèjo tolygiai ir per visas fizinio krūvio mėginio pakopas (išskyrus šeštą krūvio minutę) statistiškai reikšmingai buvo mažesnis už kontrolinès grupès tiriamuju šio rodmens kitimo greiti $(\mathrm{p}<0,05)(1$ pav. $)$

Išanalizavus JT intervalo kitimą krūvio metu nustatyta, kad krepšininkų ir nesportuojančių tiriamujų JT intervalo kitimo greitis fizinio krūvio mėginio metu mažejo tolygiai. Statistiškai patikimas JT kitimo greičio skirtumas tarp krepšininku ir kontrolinès grupès tiriamuju išryškejjo tik šeštą fizinio krūvio minutę, kai nesportuojančių tiriamųjų JT kitimo greitis padidejo $(\mathrm{p}<0,05)(2$ pav.).

Ketvirtą fizinio krūvio minutę krepšininkų santykinio rodiklio JT / RR kitimo greitis patikimai mažesnis, o šeštą - didesnis už kontrolinès grupès JT / RR kitimo greiti $(p<0,05)$. Krepšininku JT / RR kitimo greičio kreivè savita: nuo antros 


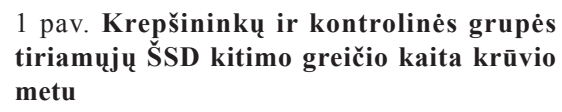

1 pav. Krepšininkų ir kontrolinès grupès tiriamųjų SSD kitimo greičio kaita krūvio metu

Pastaba. * $-\mathrm{p}<0,05$.

2 pav. Krepšininkų ir kontrolinès grupès tiriamųjų JT intervalo kitimo greičio kaita krūvio metu

Pastaba. * $-\mathrm{p}<0,05$.

3 pav. Krepšininkų ir kontrolinės grupès tiriamųjų santykinio rodiklio JT / RR kitimo greičio kaita krūvio metu

Pastaba. * $-\mathrm{p}<0,05$.

iki ketvirtos minutès JT / RR kitimo greitis mažèjo ir toliau kito nedaug. Kontrolinès grupès JT / RR kitimo greitis tolygiai mažèjo iki šeštos minutès. Pasiekus mažiausią JT / RR kitimo greičio reikšmę, kontrolinès grupès tiriamujų JT / RR kitimo greitis vèl padidèjo (3 pav.).

Šeštą fizinio krūvio minutę išryškèjo skirtumai tarp krepšininkų ir kontrolinès grupès $\mathrm{S}$ kitimo greičio rodmenu $(p<0,05)$. Palyginus krepšinin$\mathrm{ku}$ ir kontrolinès grupès $\mathrm{S}$ kitimo greičio kreives
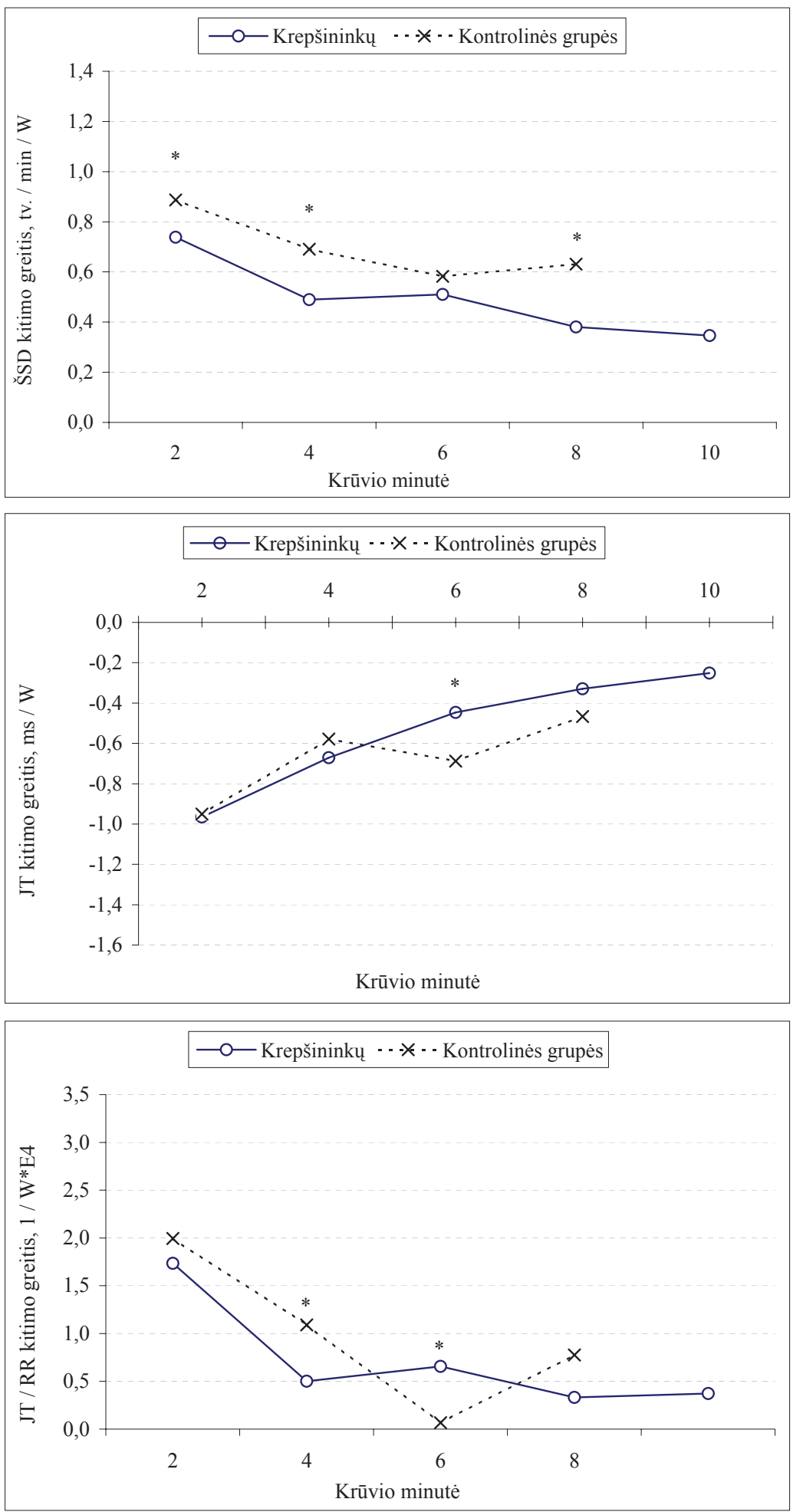

nustatyta, kad krepšininkų S kitimo greičio kaita iki šeštos minutès nedidelè, kontrolinès grupès tiriamujų — iki šeštos minutès tolygiai mažèjo, o nuo šeštos - staiga padidejo (4 pav.).

Antrą, šeštą ir aštuntą minutę išryškejjo statistiškai reikšmingas S-D kitimo greičio skirtumas tarp tiriamu grupių $(p<0,05)$. Palyginus krepšininkų ir kontrolinès grupės tiriamujų S-D kitimo greičio kreives nustatyta, kad krepšininkų S-D kitimo greitis iki aštuntos minutès mažèjo tolygiai, aštuntą - 

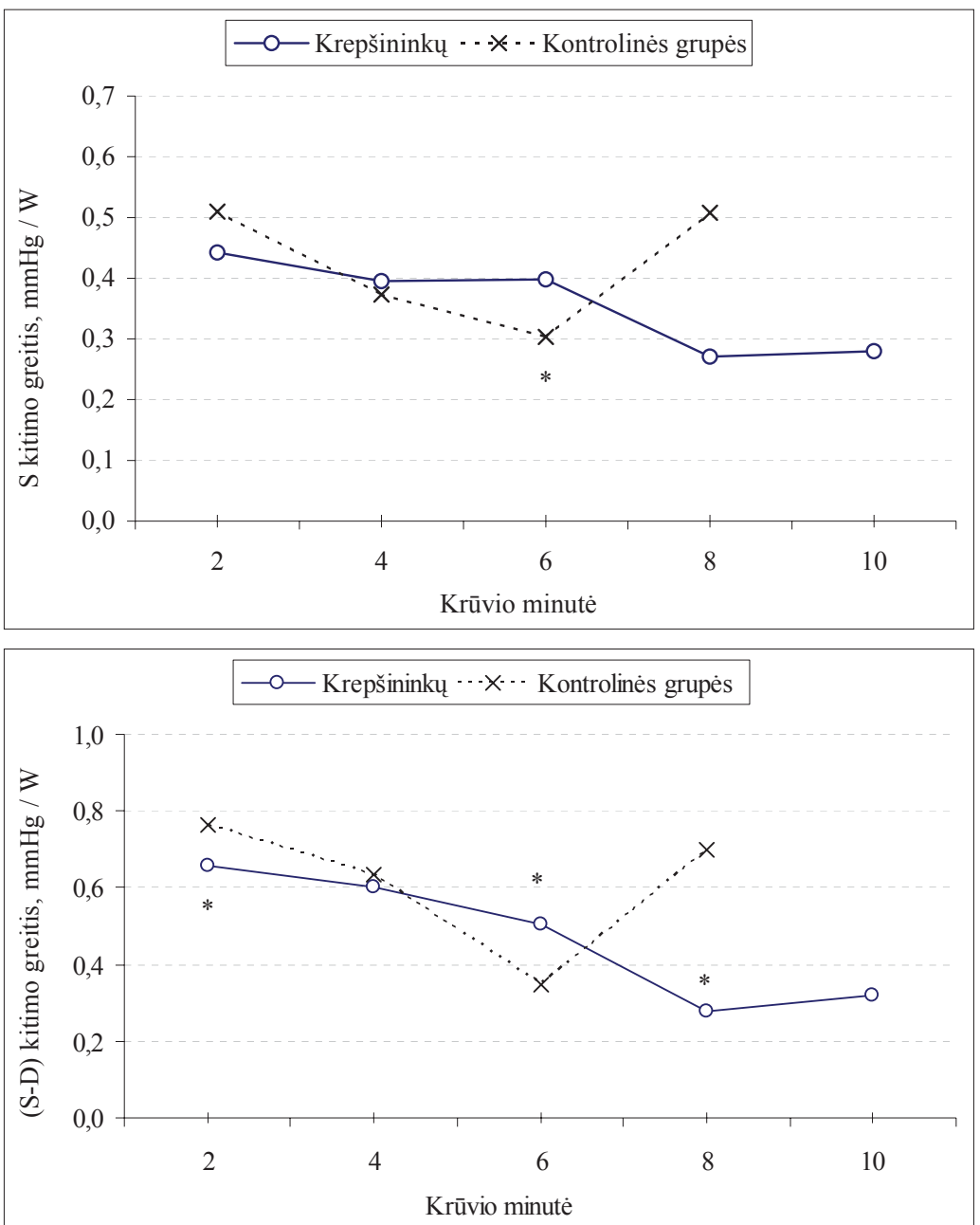

4 pav. Krepšininkų ir nesportuojančių tiriamųjų sistolinio kraujo spaudimo (S) kitimo greičio kaita krūvio metu

Pastaba. * $-\mathrm{p}<0,05$.

5 pav. Krepšininkų ir nesportuojančių tiriamu̧jų pulsinès AKS amplitudès (S-D) kitimo greičio kaita krūvio metu

Pastaba. * $-\mathrm{p}<0,05$. pasiekè mažiausią reikšmę ir nuo tada vèl didèjo. Iki šeštos minutès kontrolinès grupès tiriamujų S-D kitimo greitis mažèjo, šeštą minutę buvo mažiausias, nuo šeštos - staiga padidèjo (5 pav.).

Koreliacinè analizè parode, kad visą fizinio krūvio laikotarpi sportininku ŠSD kitimo greitis turejjo neigiama koreliacini ryši su KS miokardo masès ir MMI rodmenimis (išskyrus šeštą fizinio krūvio minutę). Koreliacinis ryšys, didinant fizinio krūvio galingumą, stiprèjo $(\mathrm{r}=-0,26$ antrą krūvio minutę, $\mathrm{r}=-0,46$ dešimtą krūvio minutę).

\section{REZULTATŲ APTARIMAS}

Miokardo prisitaikymas prie nuolatinio fizinio krūvio pasireiškia jau vaikysteje. Kai kurie autoriai teigia, kad vaikų amžiaus sportininku kairiojo skilvelio geometrija pakinta jau sportinès karjeros pradžioje (Cohen et al., 1987; Horowitz et al., 2003; Aybakan et al., 2006). J. Somauroo ir bendraautoriai $2001 \mathrm{~m}$. ištyrè $17214-19$ metu futbolininkus ir nustate reikšmingą skirtumą tarp sportininkų ir nesportuojančiujų tarpskilvelinès pertvaros, kairiojo skilvelio užpakalinès sienos storio diastolès metu bei miokardo masės (Somauroo et al., 2001). C. R. Cohen ir bendraautoriai (1987) nustatè, kad paauglių imtynininku tarpskilvelinès pertvaros storis diastolès metu buvo didesnis, o kairiojo skilvelio galinis diastolinis dydis nesiskyrè nuo nesportuojančiu (Cohen et al., 1987). Kiti autoriai nurodo reikšmingai didesni sportuojančių vaikų ir paauglių kairiojo skilvelio galini diastolini dydi (Aybakan, 2006). Šio tyrimo duomenys panašūs i pateiktus literatūroje. Tyrimo metu nustatėme statistiškai reikšmingą skirtumą tarp krepšininkų ir nesportuojančių tiriamujų tarpskilvelinès pertvaros, kairiojo skilvelio užpakalinès sienos storio, galinio diastolinio dydžio, santykinio sienos storio, miokardo masès ir miokardo masès indekso.

Atlikto tyrimo metu nustateme, kad krepšinin$\mathrm{ku}$ sistolinès funkcijos rodmuo - kairiojo skilvelio frakcinis sutrumpèjimas (FS) ir diastolinès funkcijos rodmuo (E/A) santykis reikšmingai nesiskyrè nuo nesportuojančiuju. Šie duomenys sutampa su daugelio autorių teiginiais, kad vaiku amžiaus sportininkams nustatoma normali sistoliné ir diastoliné funkcija (Somauroo et al., 2001; Aybakan et al., 2006). 
Tačiau kai kurie autoriai teigia, kad gali būti padidejęs sportininkų E bangos greitis ir E / A santykis (Pluim et al., 2000; Venckūnas ir kt., 2005). Taip atsitinka dèl geresnès sportininkų kairiojo skilvelio diastolinès funkcijos. Be to, intensyviai sportuojant retėja širdies susitraukimų dažnis, todèl pailgèja diastolinio prisipildymo laikotarpis ir sumažeja diastolinė KS funkcija (Fagard, 1997). Mūsų tirtų sportininkų diastolinès funkcijos rodiklis E / A, palyginti su nesportuojančiujų, reikšmingai nesiskyrè. Tai dar kartą patvirtina literatūros duomenis apie normalią sportininkų kairiojo skilvelio diastolinę funkciją (Fagard, 1997; Pluim, 2000).

Širdies persimodeliavimui turi itakos sporto šakos pobūdis (Fagard, 1997; Pluim et al., 2000; Venckūnas ir kt., 2005). Mokslininkai teigia, kad priklausomai nuo fizinio krūvio tipo galima išskirti dvi pagrindines kairiojo skilvelio hipertrofijos formas - koncentrinę ir ekscentrinę hipertrofiją (Fagard, 1997; Cubero et al., 2000; Pluim et al., 2000). Apžvelgus paskutinius tyrimus, kuriu metu buvo išanalizuota įvairių šakų sportininkų širdies morfometriniai duomenys, nustatyta, kad daugeliui sportininkų kairiojo skilvelio hipertrofija išsivysto dèl padidèjusio KS sienelių storio ir dèl padidèjusios KS vidinès ertmès, t. y. būdingas mišrus kairiojo skilvelio persimodeliavimo tipas (Fagard, 1997; Pluim et al., 2000). Mūsų tyrimo duomenys tai patvirtino: nustatyta tirtų krepšininkų kairiojo skilvelio hipertrofija, išsivysčiusi ir dèl KS sieneliu sustorejjimo, ir dèl KS skersmens padidejimo diastolès metu. Panašiai teigia ir kiti tyrëjai (Fagard, 1997). D. Vasiliauskas ir bendraautoriai (2006) pateikia kiek kitokius duomenis. Tyrejjai, atlikę 8-13 ir 14-17 m. krepšininku echokardiografini tyrima, nustatè, kad 14-17 m. krepšininkų tarpskilvelinès pertvaros, KS užpakalinès sienelès ir KS santykinis sienelių storis patikimai viršijo $8-13 \mathrm{~m}$. tiriamujų rodmenis, tačiau galinis skersmuo diastolès metu nesiskyrè (Vasiliauskas et al., 2006). Panašiai teigia ir kiti autoriai, tyrę suaugusius krepšininkus (Fagard, 1997; Pelliccia et al., 1999). Daroma prielaida, kad krepšininkams būdingas koncentrinis kairiojo skilvelio persimodeliavimas dèl padidèjusio sieneliu storio. Mišrų mūsų tirtu krepšininkų kairiojo skilvelio geometrijos persitvarkymo pobūdi galejo lemti treniravimosi stažas. Populiariausios Lietuvoje sporto šakos - krepšinio - atstovai pradeda reguliariai sportuoti anksčiau nei dauguma kitų sportininkų, o didesnis treniravimosi stažas gali paveikti kairiojo skilvelio persimodeliavimą. Be to, aciklinis krepšinio sporto šakos pobūdis bei didelio intensyvumo dinaminis krūvis yra specifinis, todèl gali paveikti ir ekscentrini KS persimodeliavimą. Rungtyniaudami krepšininkai daugiausia atlieka intensyvų nedidelès trukmès fizinį krūvị, o poilsio tarp intensyvios fizinès veiklos metu jie būna mažai aktyvūs. Gal ši skirtumą iš dalies galejo lemti sportinio krūvio intensyvumas ir trenerio parinkta treniruočių strategija? Tiek pasaulyje, tiek Lietuvoje nepakanka tyrimu, nagrinejjančiu vaikų ir paaugliu krepšininkų širdies morfometrijos prisitaikymą prie fizinio krūvio. Todèl tikslinga ištirti didesni vaiku ir paauglių, kultivuojančių krepšinio sportą, kontingentą. Krepšininkų ūgis ir kūno paviršiaus plotas, aišku, dažnai būna didesnis nei kitų šakų sportininkų (Pavlik et al., 2001). Tyrimo metu nustateme, kad krepšininkų ūgis patikimai viršijo nesportuojančių kontrolinès grupès tiriamujų rodiklius, bet kūno paviršiaus plotas nuo nesportuojančiujų nesiskyrè. Todèl išanalizavus santykinius (koreguotus pagal kūno paviršiaus plota) echokardiografinius rodmenis nustatytas statistiškai reikšmingas krepšininkų ir kontrolinès grupès šių rodmenų skirtumas.

Dèl ilgalaikio fizinio krūvio persimodeliuoja ne tik širdis, bet pakinta širdies ir kraujagysliu sistemos funkciniai rodmenys, viso organizmo funkcinè būsena. Norėdami išsamiau išanalizuoti krepšininkų funkciniu rodmenu kaitą fizinio krūvio metu, taikème integralios organizmo reakcijos į fizini krūvi modeli (Vainoras ir kt., 1999). Vienas plačiausiai nagrinėjamų ŠKS rodmenu yra širdies susitraukimo dažnis ( ŠSD). Vaikų ir paauglių brendimo laikotarpiu, kol galutinai nesusiformavę kraujo srovès perskirstymo mechanizmai fizinio krūvio metu, labai svarbi ŠSD kaita (Washington et al., 1994; Winsley et al., 2003). ŠSD fizinio krūvio metu pradeda didèti nuo pat fizinio krūvio pradžios ir, didejjant krūvio intensyvumui, jis didejja tiesiškai (Rowland, 1996). Ilgalaikis fizinis krūvis didina parasimpatinès nervu sistemos poveiki, dèl to sportininku ŠSD ramybès būsenoje ir fizinio krūvio metu mažesnis už nesportuojančiujų (Rowland, 1996). A. Emeljanovas ir kt. (2006), palyginę $13 \mathrm{~m}$. amžiaus žaidejjų ir kontrolinès grupès ŠSD atliekant $30 \mathrm{~s}$ vertikalaus šuoliavimo testa, nustate, kad žaidejjų ŠSD reikšmès fizinio krūvio metu statistiškai patikimai mažesnès už kontrolinès grupès (Emeljanovas ir kt., 2006). Geresnę sportininkų reguliacinès sistemos adaptaciją prie krūvio rodo ne tik mažesnès, lyginant su nesportuojančiaisiais, ŠSD reikšmès, bet ir mažesnis ŠSD kitimo greitis (Žumbakytè, 2007). Mūsų tyrimo duomenys patvirtina šiuos teiginius. Krepšininku ŠSD didejjimo greitis statistiškai patikimai mažesnis už kontrolinès grupès tiriamujų atitinkamą rodmeni ir tolygiai mažèjo beveik per visą fizinio 
krūvio mėginio laikotarpi. Tokią šio rodmens kitimo greičio kaitą paaiškina geresnè sportininkų reguliacinès sistemos adaptacija prie fizinio krūvio.

Elektrokardiogramos JT intervalas attinka širdies elektrinę sistolę ir jo trumpèjimas susijęs su širdies metabolizmo intensyvumu (Vainoras, 1999). Mūsų tyrimas parodè, kad krepšininkų JT intervalo kitimo greitis krūvio metu yra mažesnis nei nesportuojančiu tik šeštą krūvio minutę, tačiau krepšininku JT intervalo kitimo greičio kreivè tolygesnè. Tai sutampa su autorių, teigiančiu, kad sportininkų JT intervalo reikšmès bei kitimo greitis skiriasi nuo nesportuojančiujų, ir tai rodo geresni sportininku aprūpinančiosios sistemos prisitaikymą prie fizinio krūvio (Emeljanovas ir kt., 2006; Žumbakytė, 2007). Tai patvirtina ir kitu tyrèjų duomenis, teigiančius, kad vaikų ir paauglių širdies ir kraujagyslių sistemos adaptacijos prie fizinio krūvio metu svarbiausias vaidmuo tenka ŠSD ir glaudžiu ryšiu su juo susijusio JT intervalo kaitai (Winsley, 2003).

Vertinant organizmo kaip kompleksinès sistemos adaptaciją prie fizinio krūvio, mokslininkai yra pasiūlę nagrinèti rodmenis, apibūdinančius skirtingų sistemų sąsajas (Vainoras ir kt., 1999; Emeljanovas ir kt., 2006; Žumbakyte, 2007). Vienas iš jų — tai santykinis JT / RR rodmuo, parodantis širdies ir kraujagyslių sistemos funkcijos mobilizacijos dydi fizinio krūvio metu (Vainoras, 1999). Atlikto tyrimo metu nustatyta, kad krepšininkų JT / RR šeštą minutę padidejja ir statistiškai reikšmingai skiriasi nuo kontrolinès grupès. Mažiausias krepšininkų JT / RR kitimo greitis užregistruotas aštuntą fizinio krūvio minutę, kontrolinès grupès tiriamujų — šeštą. Vèliau krepšininkų šio rodmens kitimo greitis padideja nedaug, o kontrolinès grupès tiriamuju — ryškiai. Panašius duomenis pateikia ir R. Žumbakytè, nustačiusi, kad suaugusių sportininkų JT / RR kitimo greitis per paskutinę krūvio pakopą padidèja. Autore daro prielaida, kad šis rodmuo parodo sportininkų funkcinių galimybių ribą, t. y. reguliacinès ir aprūpinančiosios sistemos ribą rezerviniu galimybių mobilizacijos metu (Žumbakytè, 2007). A. Emeljanovas pateikia kitokius duomenis. Tyrèjas nenustate patikimo skirtumo tarp sportuojančiu ir nesportuojančiu 11-14 m. amžiaus berniuku JT / RR kaitos (Emeljanovas ir kt., 2006). Mūsų nuomone, krepšininku JT / RR rodmens kitimo greičio kaitos analizè rodo, kad sportuojančiu vaikų reguliacinès ir aprūpinančiosios sistemos fizinio krūvio metu suaktyvèja mažiau nei kontrolinès grupès, bet, antra vertus, į fizinị krūvị ịsitraukia per ilgesni laikotarpi. Tokius rezultatus galejjo lemti ir ilgas krepšininku treniravimosi stažas bei aciklinis krepšinio sporto šakos pobūdis. Be to, rezultatus galëjo lemti brendimo laikotarpio poveikis širdies ir kraujagysliu sistemai. Apie tai kalba ir kiti tyrèjai (Venckūnas ir kt., 2005; Emeljanovas ir kt., 2006).

Sistolinio kraujospūdžio (S) pokyčiai fizinio krūvio metu svarbūs nustatant ŠKS funkcines galimybes (Malcolm et al., 1993). Prepubertatiniu laikotarpiu sportuojančių vaikų sistolinis kraujospūdis atliekant fizini krūvị gali kisti mažiau, palyginti su širdies susitraukimo dažniu (Graetinger et al., 1995). Mūsų tyrimo rezultatai patvirtino ši teiginį: krepšininkų sistolinio kraujospūdžio kitimo greitis iki šeštos krūvio minutès beveik nekito, nuo šeštos — tolygiai mažèjo. Tai rodo, kad fizinio krūvio poveikis sportuojančiu vaiku ir paaugliu sistolinio kraujospūdžio kaitai išreikštas menkai. Panašiai teigia A. Emeljanovas, nustatęs, kad 11-14 m. sportininku sistolinio kraujospūdžio kaita fizinio krūvio metu patikimai nesiskyrè nuo nesportuojančiujuc (Emeljanovas ir kt., 2006).

Pulsine AKS amplitudè — tai sistolinio ir diastolinio kraujospūdžio skirtumas (S-D), kuris pagal integraliojo vertinimo modelị rodo vykdančiosios sistemos darbą (Vainoras, 1999). Žinoma, kad treniruojamas raumenynas lemia pulsinę AKS amplitudę (Poderys, 2004; Žumbakyte, 2007). Didesnè sportininkų pulsinės amplitudès greičio kaitos amplitude, lyginant su nesportuojančiujuc, rodo intensyvesni vykdančiosios sistemos (raumenyno) isitraukimą i fizinį krūvį (Žumbakytè, 2007). Tai patvirtina ir mūsų duomenys. Skiriasi krepšininkų ir kontrolinės grupės tiriamujų fizinio krūvio mėginio laikas, kada pasiekiama mažiausia S-D kitimo greičio reikšmè: krepšininkų mažiausia S-D greičio kitimo reikšmè užregistruota aštuntą minutę, nesportuojančių — šeštą. Tai atsitinka dèl to, kad nesportuojančiujų vykdančioji sistema nèra adaptuota prie tokio krūvio ir jų rezervinès galimybès išsenka anksčiau, lyginant su sportininkais.

Mokslinėje literatūroje aptinkama duomenu, kad sportininku kairiojo skilvelio miokardo masė (KSMM) turi ryši su ŠSD ir sistoliniu kraujospūdžiu (Graetinger et al., 1995; Karjalainen et al., 1997). Mūsų tyrimas tai patvirtino. Nustateme neigiamą krepšininku ŠSD kitimo greičio ir KSMM ryši jau antrą fizinio krūvio minutę $(r=-0,3)$. Didejjant fizinio krūvio galingumui, koreliacinis ryšys stiprejo $(r=-0,46)$. Ši reiškini galima paaiškinti taip: dèl fizinio krūvio persitvarkius KS geometrijai, galingesnis KS miokardas lemia geresnę sportininko širdies ir kraujagysliu sistemos adaptaciją prie fizinio krūvio. Nors mokslinèje literatūroje aptinkama duomenų, teigiančių, kad 
sportininkų sistolinis kraujospūdis fizinio krūvio metu turi ryši su KSMM, statistiškai patikimo koreliacinio ryšio tarp krepšininkų S kitimo greičio ir KSMM nenustateme (Karjalainen et al., 1997). Manome, kad vaikų amžiuje fizinio krūvio metu sistolinio kraujospūdžio ir jo kitimo greičio kaita nedidelè, todèl galingesnis sportininkų miokardas daugiau lemia ŠSD bei ŠSD kitimo greičio kaitą.

Tyrimas parodè, kad nagrinètų kairiojo skilvelio echokardiografinių bei širdies ir kraujagysliu sistemos funkcinių rodmenų kitimo greitis tarp krepšininkų ir nesportuojančių tiriamuju buvo skirtingas. Veloergometrinio mėginio metu registruojamo ŠSD kitimo greičio pokyčiai turi glaudu ryši su kairiojo skilvelio echokardiografiniais rodmenimis, todèl rodmenų analizè suteikia galimybę tiksliau įvertinti širdies ir kraujagyslių sistemos funkcinę būseną.

\section{IŠVADOS}

1. Krepšininkų absoliutūs ir pagal kūno paviršiaus plotą koreguoti echokardiografiniai rodmenys statistiškai patikimai buvo didesni už nesportuojančiujų, o kairiojo skilvelio funkcijos rodmenys nuo nesportuojančiujų nesiskyrè.

2. Kairiojo skilvelio echokardiografiniu rodmenų bei širdies ir kraujagysliu sistemos funkcinių rodmenų kitimo greitis tarp krepšininkų ir nesportuojančių tiriamujų buvo skirtingas. Krepšininku ŠSD ir JT intervalo kitimo greitis fizinio krūvio metu buvo patikimai mažesnis už nesportuojančiujų.

3. Krepšininkų kairiojo skilvelio miokardo masė glaudžiai susijusi su ŠSD kitimo greičiu fizinio krūvio metu.

\section{LITERATŪRA}

Ayabakan, C., Akalin, F., Mengütay, S. et al. (2006). Athlete's heart in prepubertal male swimmers. Cardiology in the Young, 16 (1), 61-66.

Biggiero, L. (2001). Sourus of complexity in human systems. Journal of Nonlinear Dynamics. Psychology and Life Sciences, 5, 1, 379.

Du Bois, D., Du Bois, E. F. (1916). A formula to estimate approximate surface area if height and weight be known. International Medicine, 17, 129-171.

Cohen, C. R., Allen, H. D., Spain, J. et al. (1987). Cardiac structure and function of elite high school wrestlers. American Journal of Diseases of Children, 141, 576-810.

Corrado, D., Basso, C., Schiavon, M., Thiene, G. (1998). Screening for hypertrophic cardiomyopathy in young athletes. The New England Journal of Medicine, 339 (6), 364-369.

Cubero, G. I., Batalla, A., Reguero, J. J. R. et al. (2000). Left ventricular mass index and sports: The influence of different sports activities and arterial blood pressure. International Journal of Cardiology, 75, 261-265.

Emeljanovas, A., Venskaityte, E., Daniusevičiūte, L., Poderys, J. (2006). Reguliarių sportinių žaidimų ir cikliniu sporto šaku pratimu poveikis $11-14$ metu berniuku raumenu bei širdies ir kraujagysliu sistemoms. Ugdymas. Kūno kultūra. Sportas, 3 (62), 3-10.

Fagard, R. H. (1997). Impact of different sports and training on cardiac structure and function. Cardiology Clinics, $15(3), 397-412$.

Graetinger, W. F., Smith, D. H., Neutel, J. M. et al. (1995). Relationship of ventricular structure to maximal heart rate during exercise. Chest, 107 (2), 341-345.

Horowitz, E. S., Petkowicz, R., Meyer, F. (2003). Left ventricular structure and function in adolescent swimmers. Cardiology in the Young, 13 (1), 33-34.

Karjalainen, J., Mantysaari, M., Viitasalo. M., Kujala, U. (1997). Left ventricular mass, geometry, and filling in endurance athletes: Association with exercise blood pressure. Journal of Applied Physiology, 82 (2), 531-537.

Lang, R. M., Bierig, M., Devereux, R. B. et al. (2005). Recommendations for chamber quantification: A report from the American Society of Echocardiography's Guidelines and Standards Committee and the Chamber Quantification Writing Group, developed in conjunction with the European Association of Echocardiography, a branch of the European Society of Cardiology. Journal of American Echocardiography, 18, 1440-1463.

Malcolm, D. D., Burns, T. L., Mahoney, L. T., Lauer, R. M. (1993). Left ventricular mass and exercise responses predict future blood pressure. The Muscatine Study Pediatrics, 92 (5), 703-709.

Pavlik, G., Olexo, Z., Osvath, P., Sido, Z., Frenk1, R. (2001). Echocardiographic characteristic of male athletes of different age. British Journal of Sports Medicine, 35, 95-99.

Pelliccia, A, Culasso, F., Di Paolo, F. M., Maron, B. J. (1999). Physiological left ventricular cavity dilatation in elite athletes. Annals of International Medicine, 130 (1), 23-31.

Pluim, B. M., Zwinderman, A. H., van der Laarse, A., van der Wall, E. E. (2000). The athlete's heart: A metaanalysis of cardiac structure and function. Circulation, 101, $336-344$

Poderys, J. (2004). Kineziologijos pagrindai: mokomoji knyga. Kaunas.

Rowland, T. W. (1996). Development Exercise Physiology. USA.

Somauroo, J., Pyatt, M., Jackson, R., Perry, Ramsdale, D. (2001). An echocardiographic assessment of cardiac morphology and common ECG findings in teenage professional soccer players: Reference ranges for use in screening. Heart, 85 (6), 649-654.

Vainoras, A., Gargasas, L., Jaruševičius, G., Šilanskienè, A. et al. (1999). Veloergometrija ir sisteminiu vertinimu galimybė. Lithuanian Journal of Cardiology, 6 (2), 760-762.

Vasiliauskas, D., Venckūnas, T., Marcinkevičienè, J., Bartkevičienè, A. (2006). Development of structural cardiac adaptation in basketball players. European Journal of Cardiovascular Prevention and Rehabilitation, 13, 985-989.

Venckūnas, T., Vasiliauskas, D., Marcinkevičienė, J., Raugalienè, R. (2005). Jaunų krepšininkų širdies kairiojo skilvelio struktūra ir funkcija. Ugdymas. Kūno kultūra. Sportas, 2 (56), 55-62. 
Washington, R. L., Bricker, J. T., Alpert, B. S. et al. (1994). Guidelines for exercise testing in the pediatric age group. From the Committee on Atherosclerosis and Hypertension in Children, Council on Cardiovascular Disease in the Young, the American Heart Association. Circulation, 90, 2166-2179.

Winsley, R. J., Armstrong, N., Bywater, K., Fawkner, S. G.
(2003). Reliability of heart rate variability measures at rest and during light exercise in children. British Journal of Sports Medicine, 37 (6), 550-552.

Žumbakytè, R. (2007). Krepšininku ir futbolininku funkcinès būklès ypatybès naudojant integraliojo vertinimo modeli: daktaro disertacija. KMU.

\title{
STRUCTURAL CARDIAC ADAPTATION AND PARAMETERS OF CARDIOVASCULAR SYSTEM IN 12 TO 17-EAR OLD BASKETBALL PLAYERS
}

\author{
Aldona Bartkevičiené $\dot{1}^{1,4}$, Alfonsas Vainoras ${ }^{2}$, Dalia Bakšiené ${ }^{2}$, \\ Nijolė Raškauskiené $\dot{1}^{1}$, Sigita Kibildiené $\dot{e}^{3}$ \\ Institute of Psychophysiology and Rehabilitation c/o Kaunas University of Medicine ${ }^{1}$, Palanga, \\ Kaunas University of Medicine ${ }^{2}$, Kaunas, Klaipeda Sports Medicas Centre, \\ Klaipèda Children Hospital ${ }^{4}$, Klaipeda, Lithuania
}

\begin{abstract}
Specific features of the adaptive changes of the cardiovascular system of the children and adolescent basketball players are still insufficiently investigated.

The aim of the study was to evaluate the development of echocardiographic indices of the left ventricle and describe alternations in the speed of changes in the parameters of cardiovascular system during exercise test in 12-17 year-old basketball players.

Methods: 62 male basketball players between 12 and 17 years and 168 healthy non athletes controls of the same age and gender were involved in the study.

All the subjects were examined by M-mode and 2-dimensional Doppler echocardiography. Left ventricular enddiastolic internal diameter (LVIDd), posterior wall thickness (LVPW), as well as interventricular wall thickness (IVS) were measured from M-mode echocardiography. Left ventricular mass (LVM), left ventricular mass index (LVMI), body size-adjusted LVIDd, LVPW, IVS, LVM, shortening fraction (SF), relative wall thickness (RWT) were calculated by using the formulas. Diastolic parameters including peak E wave, peak A wave were measured from Doppler echocardiography, their ratio $\mathrm{E} / \mathrm{A}$ was calculated.

All the participants of the study performed a graded exercise test on a cycle ergometer. 12 ECG standard derivations were synchronically recorded every second minute. The following functional parameters and their rate of change were estimated: heart rate (HR), JT interval, RR interval, systolic blood pressure(S), diastolic blood pressure (D), pulse blood pressure amplitude (S-D), JT / RR ratio.

Compared with controls the basketball players showed a significantly greater absolute and body size-adjusted LVID, IVS, LVPW and LVM $(\mathrm{p}<0.001)$. SF and $\mathrm{E} / \mathrm{A}$ ratio did not differ between the basketball players and the controls.

Differences in the speed of changes in HR, JT, JT / RR, S and (S-D) between the basketball players and the controls were reported. The speed of change of HR in the controls was higher than that in the basketball players during all phases of exercise test with the exception of 6-th $\min (p<0.05)$. We found statistically significantly higher speed of changes in JT in the controls than that of the basketball players in the 6-th $\min (\mathrm{p}<0.05)$. The speed of change of HR correlated significantly in the basketball players to LVM in all phases of the load $(r=-0.4-0.5)$, the speed of changes in JT - in the 6-th $\min$ of the load $(r=0.3)$.

Our study revealed that children, who trained basketball regularly, had significantly greater left ventricular cavity, thicker interventricular wall and left ventricular posterior wall, greater left ventricular mass compared to non trained controls. The speed of changes in HR in the controls was higher compared to the basketball players, and that suggests a better adaptation of cardiovascular system of basketball players to physical exercise.

There was correlation between speed of changes in functional parameters and echocardiographic indices in basketball players.Athletes who reached a greater speed of changes in HR during exercise test had a tendency to develop greater LVM.
\end{abstract}

Keywords: cardiovascular system, speed of changes in functional parameters, echocardiography.

Gauta 2008 m. rugsèjo $30 \mathrm{~d}$.

Received on September 30, 2008

Priimta 2008 m. gruodžio $9 \mathrm{~d}$.

Accepted on December 9, 2008
Aldona Bartkevičienė

Kauno medicinos universiteto

Psichofiziologijos ir reabilitacijos institutas

(Institute of Psychophysiology and Reabilitation

c/o Kaunas University of Medicine)

Vydūno al. 4, LT-00135 Palanga

Lietuva (Lithuania)

$\mathrm{Tel}+370846484156$

E-mail abartkeviciene@hotmail.com 